Journal

of Geography

Politics and Society

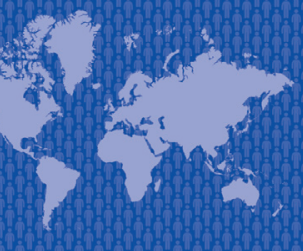

7(1)/2017

\section{Journal of Geography, Politics and Society}

$2017,7(1), 60-69$

DOI 10.4467/24512249JG.17.008.6207

\title{
SURFACE PROSPECTION OF BURIAL GROUNDS AND NEW RESEARCH TOOLS (ON THE EXAMPLE OF THE STUDY OF CHANGES IN CEMETERY BOUNDARIES)
}

\author{
Anna Majewska \\ Department of Political and Historical Geography and Regional Studies, The Faculty of Geographical Sciences, Łódź University, S. Kopcińskiego 31, 90-142 Łódź, \\ Poland, \\ e-mail: anna.majewska@op.pl
}

\section{Citation}

Majewska A., 2017, Surface prospection of burial grounds and new research tools (on the example of the study of changes in cemetery boundaries), Journal of Geography, Politics and Society, 7(1), 60-69.

\begin{abstract}
Basing on own experiences in studying cemetery space, the possibilities of using LiDAR visualization in acquiring information on changes in the boundaries of Christian and Jewish necropolises were demonstrated on selected examples. The application of the methods indicated in the article comprises the significant supplementation of terrain inspection, considerably expanding knowledge about a given site. The use of digital elevation models has been popular since their introduction, especially in the archaeological community, as it allows for feature recognition without conducting invasive prospection, including excavation. As it has turned out, in the course of the research conducted by the author, the use of LiDAR tools should be an integral part of the geographical analysis. This highlights the need to promote interdisciplinary in the research on cultural heritage sites.
\end{abstract}

\section{Key words}

LiDAR, Jewish cemetery, Protestant cemetery, Catholic cemetery, boundaries, inventory, cultural heritage.

\section{Introduction}

The boundary of the cemetery - trench, wall, earthwork - separates the two spheres: the sacred and the profane. It designates two areas: designed for the living and the dead. This boundary is therefore extremely important; separating these two worlds has almost always had not only a practical role, but above all socio-cultural and closely associated with religious rituals and rites (cf. Duma, 2010; Komorowski, 2011). In the years 2015-2016, 93 cemeteries of two religions: Christianity and Judaism 1 , were inventoried. During the research, attention was drawn, among others, to the cemetery borders and the issue of their variability over time as well as the effect of

149 Jewish cemeteries in the Silesian Voivodeship, 30 Protestant cemeteries in the Elk Lake District, 13 Protestant cemeteries in Pabianice poviat (Lodz Voivodeship), and 1 historic Catholic cemetery located in Lelów (Częstochowa poviat, the Silesian Voivodeship) were inventoried. 


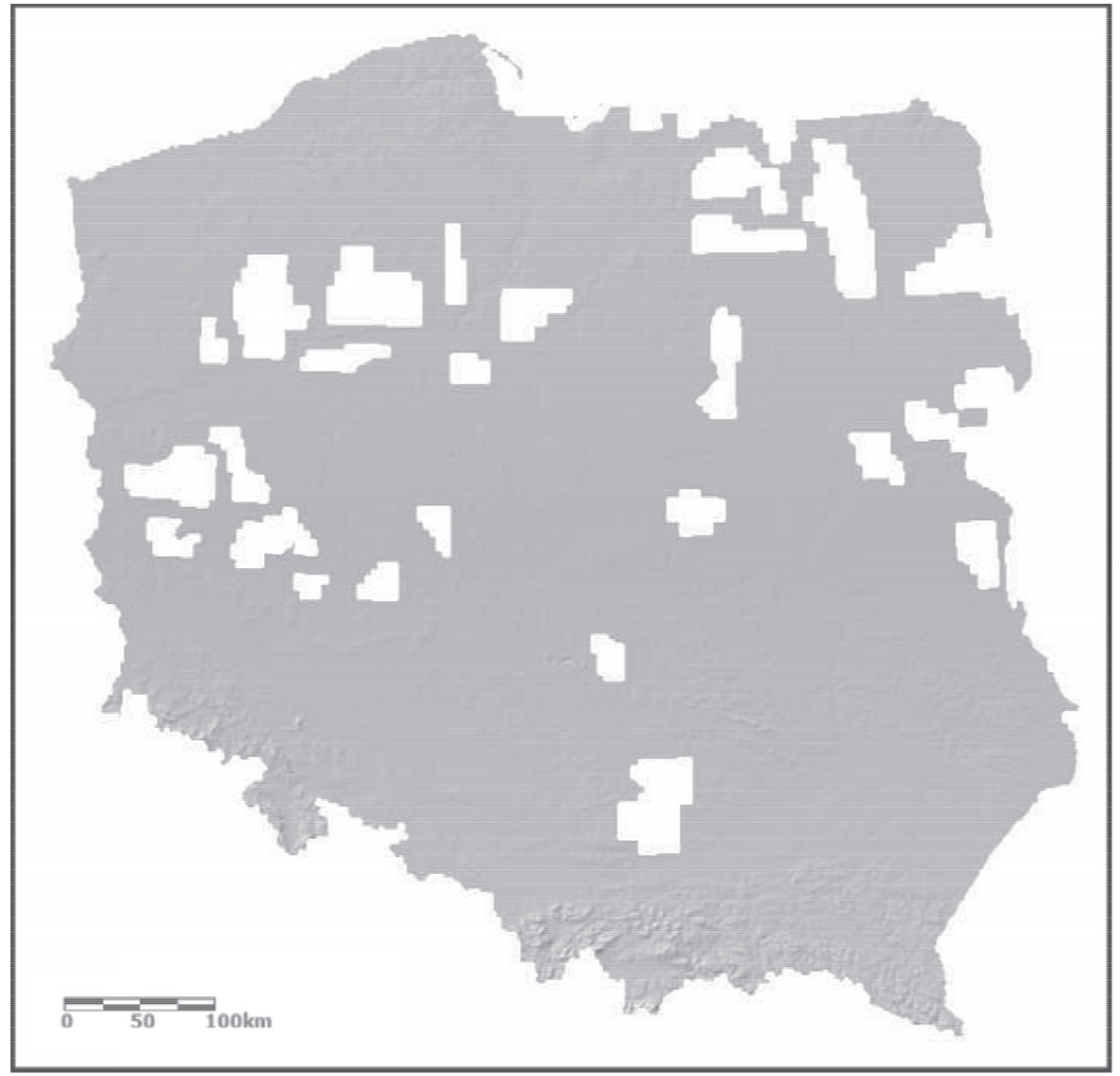

Fig. 1. Range of visualization of digital elevation data for the area of Poland, available through the Geoportal platform Source: www.geoportal.gov.pl [26/09/2016].

socio-cultural determinants and environmental conditions. Detailed surface prospection resulted in numerous observations, including those related to the methodology and directions of the conducted analyzes, as well as the possibility of using new research tools for their purpose. Therefore, on the basis of the research, it was decided to present the question of the use of surface area visualization techniques to recognize the relics of the site boundaries and observe the change in their course. Laser scanning data used for this purpose are now successfully employed especially in terms of recognition of archaeological features, for instance, trenches, and settlement and defense features ${ }^{2}$. This article presents the use of new techniques from the perspective of geographical research on cultural heritage sites, namely cemeteries. The aim of the paper is to identify the possibilities of using the currently widely available LiDAR ${ }^{3}$ elevation

2 This issue is discussed by, among others: P. Franczak and W. Jucha (2015), C. Sobczak (2015), F. Wałdoch (2014); and the use of Geoportal in the studies (but without the analysis of the LiDAR module) by H.Lepionka (2014).

3 Abbreviation for light detection and ranging (Wałdoch, 2014 , p. 151). LIDAR is a method of obtaining three-dimensional image of surface terrain from airborne laser scanning models in the study of changes in the boundaries of burial sites, especially if the researcher struggles with a lack of historical data and historical indications on necropolis they are interested in.

Ready elevation models widely available through Geoportal cover approximately $80 \%$ of the country (Fig. 1). They have been prepared in several versions (http://www.geoportal.gov.pl/dane/numerycznemodele-wysokosciowe). In this study, models resulting from the Information System of the National Guards (ISOK) project were used. They are now the most accurate among the available ones. The first one is imaging of the detailed terrain at ground level generated by grayscale hillshade. Important for the correct reading of these images is the information on the direction of the light. In this model, the rays illuminating the area were projected from the northwest. This means that, if the south-east area of the feature is shaded, it is a convex form of terrain, for example, a hill or earthwork. In the case of cemeteries, graphics obtained in this way allows for acquiring information about their composition: the distribution

data (more information here: http://www.lidar-uk.com/usage-of-lidar/ [24.09.2016]. 
of individual quarters and avenues, if the layout remains apparently blurred by, for instance, a disorderly vegetation succession in the area of the cemetery. The second type of the available elevation model is an image which changes depending on the settings of scale and spatial range the researcher is interested in. This is a visualization of the terrain designed according to the characteristics typical of hypsometric maps, but with a dynamic color scale. Both types of image allow for the accurate identification of the terrain profile of the given feature and its documentation.

\section{The use of airborne laser scanning in the analyzes of the boundaries of cemeteries}

The analysis of terrain visualization obtained from laser scanning data (LiDAR system) combined with terrain observations allows for diagnosing suspected processes of spatial development of selected cemetery complexes, about which little is known within preserved historical sources. This hypothesis was confirmed in the results of research on Jewish and Christian cemeteries. The findings broaden knowledge not only about the cemeteries themselves but, above all, about the history of the community managing them until World War II.

A very clear example on which the application of LiDAR technology in the studies of the necropolis' range can be demonstrated is an analysis of the area of the Jewish cemetery in Żarki. A seemingly unified layout of the necropolis in the form of a rectangle, with no apparent internal divisions visible during the terrain inspection as well as observation of aerial photographs, changes significantly after the application of the shading layer proposed by the ISOK project ${ }^{4}$. In the north-western part of the cemetery, a clear spatial structure in the shape of a square having about 80 meters per side is visible (Fig. 2). Moreover, in the central part of the southern boundary of the feature, a regular, less regular elevation shape (perhaps the outline of the original gate building) and the line leading from it (perhaps a negative trace of the communication route leading in the direction of the current southern border of the cemetery) can be seen. The borders of the structure are probably constituted by the remains of a stone wall and/ or stone foundations. The genesis of the form is not

\footnotetext{
4 The study used a ready-made digital elevation models developed for the platform www.geoportal.gov.pl under the ISOK project - Information System of the National Guards) (http://www.geoportal.gov.pl/dane/numeryczne-modelewysokosciowe) .
}

clearly explained. Wojciech Mszyca, the guardian of the cemetery, is of the opinion that this may be the boundaries of the first Jewish cemetery in Żarki. According to his hypothesis, after filling the first Jewish cemetery, the Jews from Żarki bought land for a new cemetery, which is now an old devastated cemetery. However, after filling up the new burial place, they returned to the first Jewish cemetery, expanding its area towards the south and east. Although matzevas older than the date of creation of the new Jewish cemetery have not been found there, the theory may hold true because employees of the Institute of Jewish Studies of the Jagiellonian University who conduct inventory research concluded that there is a likelihood of the occurrence of older burials in this area ${ }^{5}$. The author of this paper proposes the hypothesis assuming that the quadratic form is the cemetery area, which was fenced in the 19th century ${ }^{6}$. It is supported by the evident regular drawing of the boundaries of the quadratic form discussed. It should be noted, however, that it is extraordinary even in the case of the preserved stone cemetery fences. The author presumes that the form does not have medieval origins. The first cemeteries were not so regular. The first late-medieval and early modern cemeteries took on rather irregular shapes, they were surrounded with ditches or earthworks, and later they were also fenced. It is doubtful that the original boundaries of the cemetery have survived in such a good condition until today. In addition, it would have seemed unnatural to establish the first cemetery at a greater distance from the town center than the cemetery now known as "the old". In the area of the modern Silesian Voivodeship, reverse trends prevailed, where as settlement expansion and village development proceeded, cemeteries, especially Jewish ones, were pushed in time to areas away from the buildings ${ }^{7}$. The history of the new Jewish cemetery, whose land was a matter of dispute, which began in 1836 between the Jews and the Pauline monastery of Leśniów, should also be taken into account. It started at a time when they wanted to surround the cemetery with a wall. The Jewish community maintained that they had founded the cemetery with the knowledge of the land owners on the manor grounds, not monastery grounds. However, it turned out that the land belonged to the monks ${ }^{8}$. The cemetery area is a com-

\footnotetext{
5 Information obtained from the guardian of the cemetery - W. Mszyca.

6 The cemetery was founded in 1821. According to the record in the inventory card, however, it was the third Jewish cemetery founded in Żarki (Mszyca, /no data/).

7 More on this subject: A. Majewska (2016).

8 The information about the site's history derives from the inventory card of the new Jewish cemetery in Żarki drawn by
} 


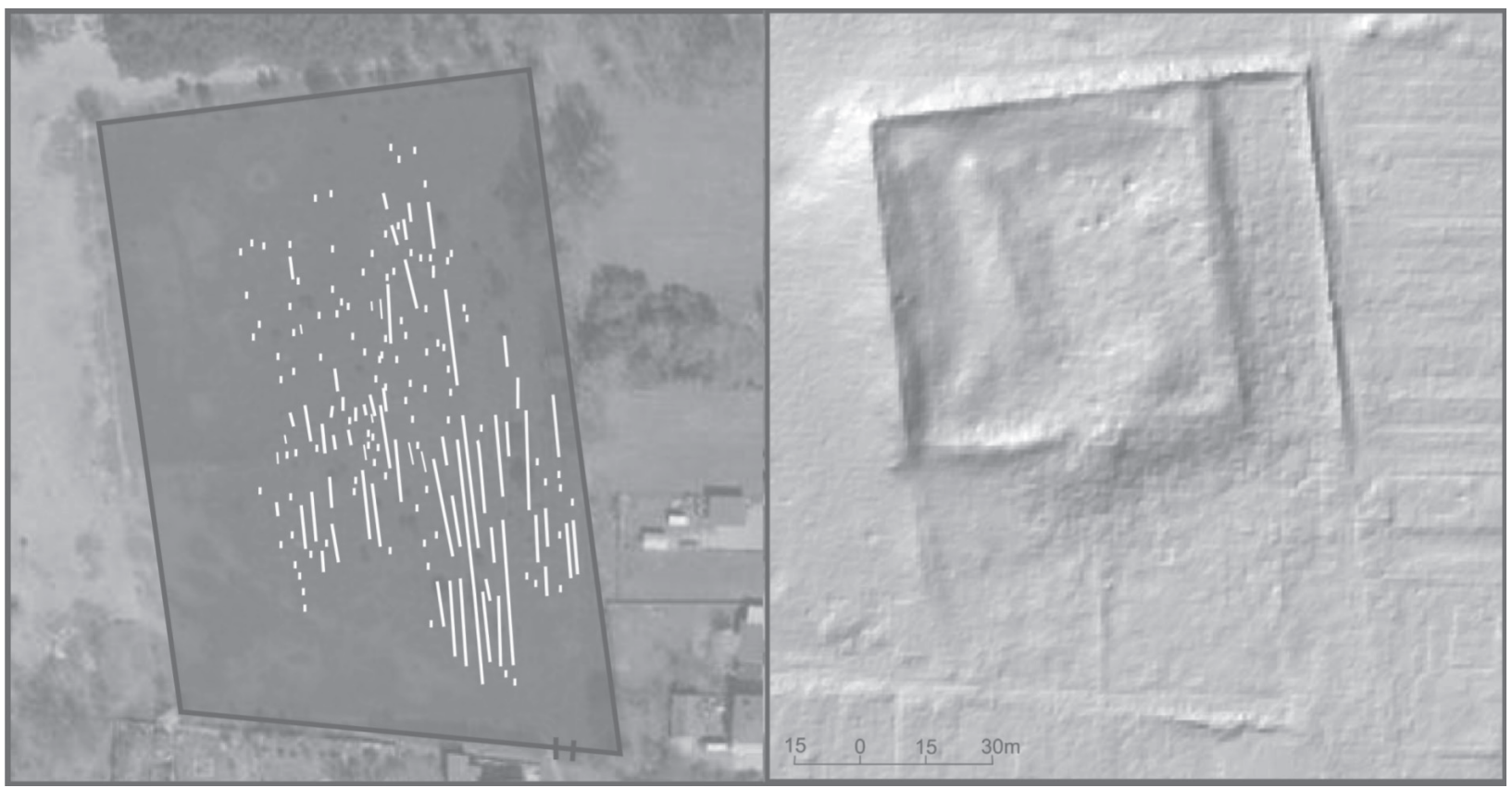

Fig. 2. New Jewish cemetery in Żarki: site plan and LiDAR image

Source: Own study on the basis of the maps www.geoportal.gov.pl [24/09/2016].

pletely sandy hill, perhaps this is why the relics of the old cemetery wall are so clear (lack of high vegetation, among others). After settling in Żarki in the 17th century, the Jews probably founded cemetery at the site of the currently old cemetery. After filling it up, in the search for another location, they established a new cemetery in 1821. It should further be noted that in the LiDAR imaging, this feature is the clearest anthropogenic surface form throughout the town and its immediate surroundings. W. Mszyca mentioned that, under the relics of the stone wall, there are probably broader foundations. Unfortunately, these speculations cannot be confirmed any time soon because conducting archaeological surveys is not possible due to the nature of the site and principles of Jewish religion. Therefore, non-invasive methods which have not yet been fully used in this field remain. Undoubtedly, the spatial arrangement of the new Jewish cemetery site in Żarki is unique in the voivodeship and it is worth conducting detailed research on its origins.

Another interesting case illustrating the change in the spatial arrangement of the site is the Jewish cemetery situated in Janów near Żarki. Little is known about the history of this burial site. The available information, however, provides knowledge about the fact that this cemetery was established earlier than the necropolis of Częstochowa, probably in the 17 th century, becoming the burial site not only for the local Jewish community but also for Jews from Częstochowa (http://www.sztetl.org.pl/pl/article/

W. Mszyca. It was made available from the author's collection. janow/5,historia/). Since this is the only Jewish cemetery in Janów, the author guesses that its area could be expanded by purchasing additional land. The necropolis has undergone considerable devastation during the World War II, therefore, the terrain inspection did not result in much information. Nevertheless, during the inventory, the author recorded the existence of the relics of the oldest burials in the southern part, and younger burials, probably prewar (traces of walled tombs/box graves), on the northern edge of the cemetery complex. In addition, near the southern border of the modern cemetery wall, the remains of probably the original cemetery fence, which was made of chipped limestone, were identified (Fig. 3). Only the image obtained through the airborne scanning laser shows what cannot be seen on the orthophotomap and in the terrain due to the dense vegetation of the cemetery. In the LiDAR visualization, there is a clear outline of the earlier boundaries of the cemetery. Its area before the expansion was approximately two thirds of the current surface $^{9}$. The shape of the preserved foundations may also indicate the location of the funeral home, which probably was the gatehouse object. It should be noted that the current fence was built in the 90 s of the 20th century. At that time, the southern border of the cemetery, which is confirmed by the inspection, was redesignated, that is moved south and laid

\footnotetext{
9 Inside, an even smaller regular form is visible, which may suggest that the surface of the cemetery has been changed twice.
} 


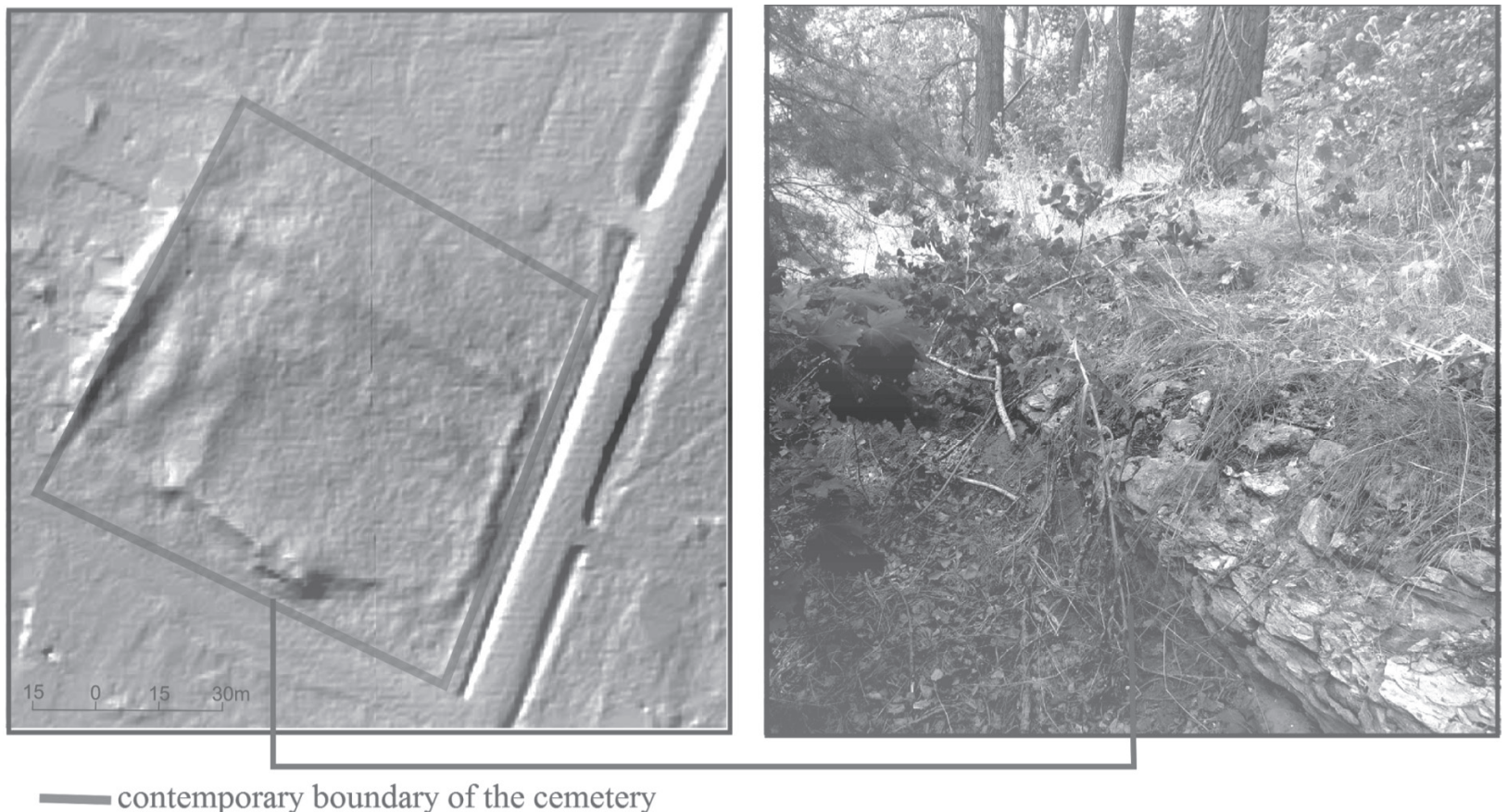

Fig. 3. Jewish cemetery in Janów: LiDAR image and the relic of the original cemetery boundary (stone wall)

Source: Own study on the basis of the maps www.geoportal.gov.pl [24/09/2016].

out parallel to the road (on the inside of the fence, there is a clear free space).

Interactive visualizations allow for detailed analysis of the terrain, including the designation of the range of burial grounds, which were used in the first place. Extremely useful in this regard is the hypsometry tool with a dynamic color scale (available through Geoportal ${ }^{10}$ ), thanks to which, a very detailed picture of the terrain can be obtained. This method was used for analyzing the surface of, among others, the old Jewish cemetery in Cieszyn and the Catholic cemetery in Lelów. In the case of the first cemetery, within its range, what is clearly visible in the visualization is the escarpment and post-exploitation pit lowering, where burials were conducted in subsequent stages of the operation of the cemetery. This elevation over the escarpment is a primary part of the complex (Fig. 4). The same situation occurs in the Catholic cemetery in Lelów, where the highest point of a former castle hill comprises the oldest burial place (Fig. 5). The hypothesis was further confirmed by the detailed inventory of the cemetery, which resulted in the designation of the alleged range of 19th-century cemetery on the basis of the distribution of the oldest burials (information contained in the inscriptions was the key determinant) ${ }^{11}$. Conducting research using LiDAR

\footnotetext{
10 View Service WMS.

11 Research was done within the project Places of memory and forgetting. Interdisciplinary research on the northern part of Jura Krakowsko-Częstochowska implemented within the
}

data is especially promising in relation to the objects on which information cannot be obtained through other methods, for instance, when archival search does not produce effects and excavation exploration is impossible for various reasons.

However, the use of laser scanning visualization in the burial studies does not always bring satisfactory results. Out of 49 Jewish cemeteries on the territory of the Silesian Voivodeship, which the author had analyzed, only in a few cases, information was obtained about the change of borders. This was related to the fact that Jewish cemeteries, for the most part, were founded on the outskirts of urban areas, and with their development, most of them were found in the built-up area. Thus, their peripheral boundaries were often subject to minor changes (for example, change associated with the expansion of communication routes), and the same boundaries have rarely preserved to this day in the form of earthworks, which would represent clear terrain forms. What is more, the areas of Jewish cemeteries were mostly severely devastated during World War II and in the postwar period (cf. Majewska, 2016). The situation is different in the case of the Protestant cemeteries,

National Programme for the Development of Humanities of the Ministry of Science and Higher Education under the direction of Dr. Olgierd Ławrynowicz in collaboration with students of archeology: Mateusz Grzelak (University of Łódź), Konrad Kempa (UŁ), Ewelina Miksa (UŁ), Bartosz Puliński (UŁ), Aleksandra Uniszewska (University of Wrocław), Dominika Węclewska (UŁ), Piotr Zwierzchowski (UŁ). 

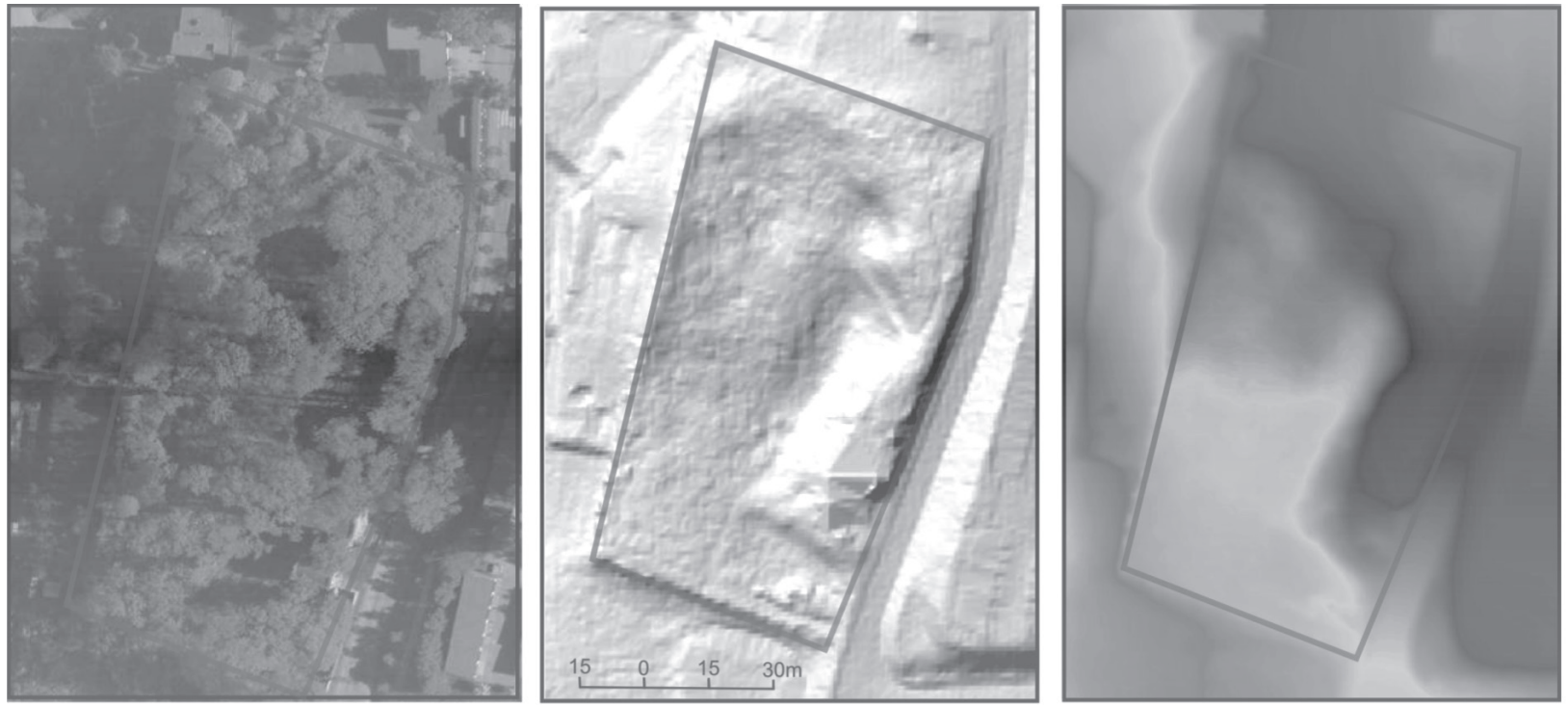

Fig. 4. Old Jewish cemetery in Cieszyn. View of (from left): orthophotomap, terrain in LiDAR visualization, terrain in the hypsometric image with a dynamic color scale

Source: Own study, on the basis of the maps www.geoportal.gov.pl [09/24/2016].

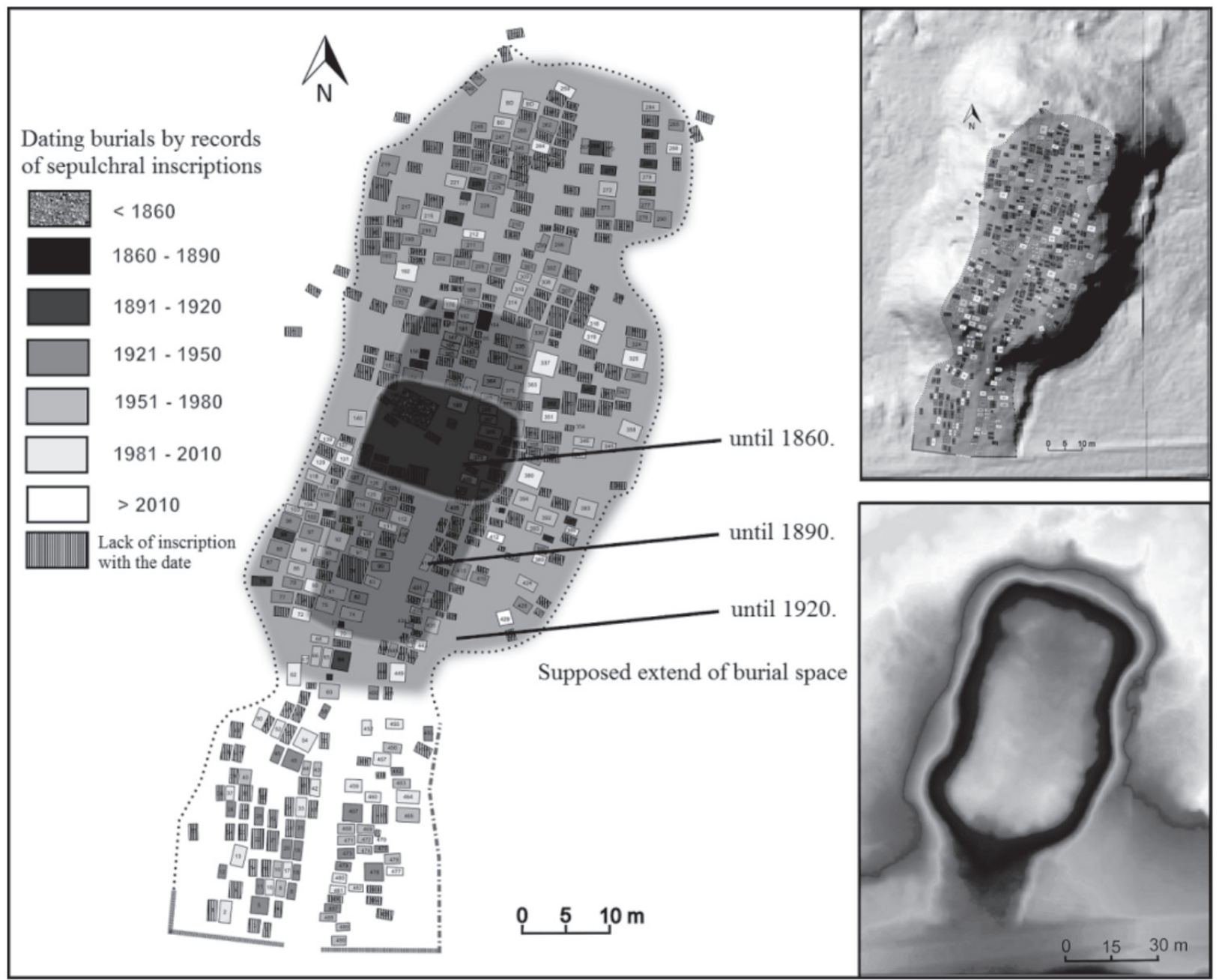

Fig. 5. Old Catholic cemetery in Lelów - spatial development of the cemetery (thumbnails: LiDAR graphics and hypsometric image with a dynamic color scale)

Source: Own study on the basis of the maps www.geoportal.gov.pl [24/09/2016]. 

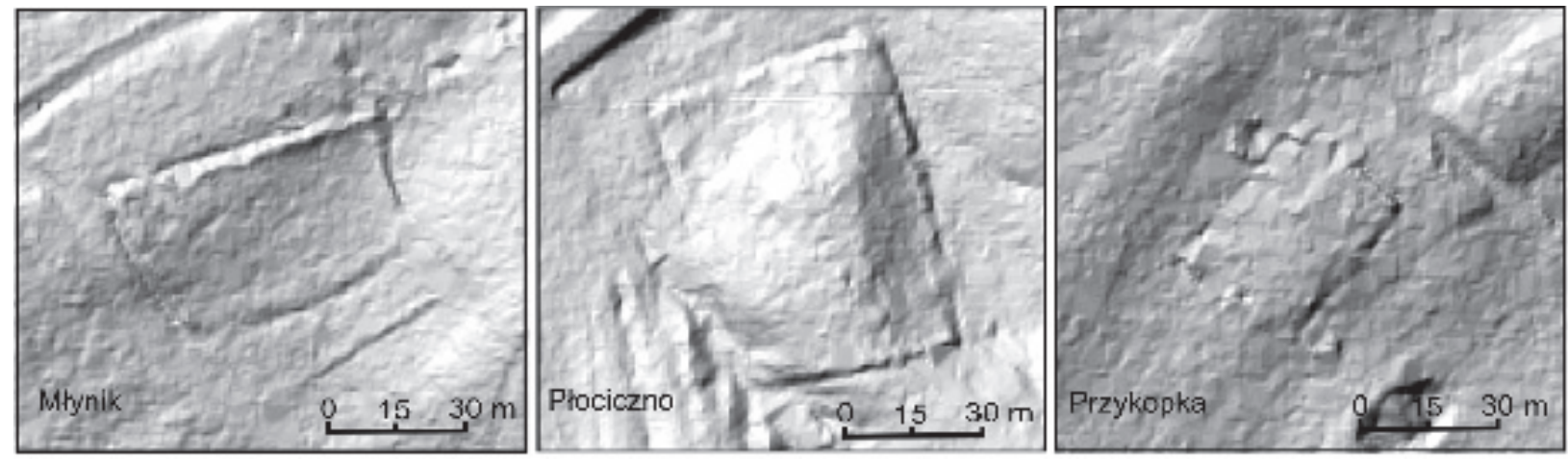

Fig. 6. Examples of the borders of the Ełk Lake District Protestant cemeteries in LiDAR visualization

Source: Own study (LiDAR data from the ISOK project: www.geoportal.gov.pl [09/24/2016]).

especially those which were established away from buildings and which today are found in a similar spatial context. This applies especially to woodland within which human intervention since the end of the operation of the cemetery has been small (excluding the devastation caused within objects). For 32 out of 43 inventoried Protestant cemeteries, it was possible to analyze their boundaries using LiDAR data. Visualizations extremely clearly showed their course, and this is because they have mostly a character of earthworks or trenches which have been preserved in a good condition. The use of this method in conducting research was particularly useful because of the difficulties in conducting surface prospection of multiple objects. Ełk Lake District cemeteries, such as Płociczno, Młynik, and Przykopka (fig. 6), are located away from the towns, in the thicket of the forest. Many-year vegetation succession in the areas of usually small Evangelical cemeteries often resulted in almost complete obliteration of the relics of the former spatial arrangements. This reduced considerably the possibility of documenting in the form of drawings and photographs, as well as taking the necessary measurements for further research. Often it was possible to draw up the basic characteristics of the object only through the graphical visualizations, especially in the cemeteries to which access was difficult or impossible, for example, if they are surrounded by wetlands or wire under voltage.

During the inventory of the Evangelical cemetery in Krokocie, no above-ground relics of burial space division were observed due to dense vegetation. Only anomalies reflected in the digital elevation models (Fig. 7) allowed for full interpretation of the studied site. Two internal divisions of the necropolis are clearly shown on the maps in the form of earthworks. The first one is located at a height of one third of the current cemetery area on the west side, and the other more or less in the middle of the site. Line objects are located on the north-south axis and their relative heights are equal to the external cemetery earthen ramparts. This may be the evidence of the development of the cemetery and at least two-stage expansion of its borders from the west side (the highest point of the elevation of the local land) to the east. This hypothesis is further supported by the existence of the road which previously led to the cemetery from the west ${ }^{12}$. In addition, during the inventory of the cemetery area, it was found that preserved tombstones appeared only in the eastern part of the site (marked on the plan - Fig. 7). Next to the few tombstones whose origin was determined to date back to the end of the 19th century/beginning of the 20th century (having, among others, inscriptions from the year 1912), there were tombstones from the years $1923,1924,1935,1936,1939$, and the post-war years of 1947, 1964, 2012. In the eastern part, there are also 2 war graves: one of an unknown German soldier and two of unknown Russian soldiers, who died in 1914. It is worth noting that the burials of the fallen were carried out at that time in the youngest, unused part of the burial ground, which further supports the rightness of the hypothesis. Perhaps conducting another terrain inspection during the fall or early spring ${ }^{13}$, when vegetation is most scarce, would reveal the presence of the relics of older burials in the western part and finally confirm the suspicions.

Sometimes the relics of the original boundaries of the cemetery leave only a slight mark on the ground and cannot be read from the LiDAR maps. This was the case, among others, with Evangelicalwar cemetery located in Bechcice in Pabianice County. Visualization of laser scanning clearly marked the boundaries of the cemetery originating from the time of World War I, but only terrain verification enabled accurate outlining of the range of World War

12 The road is marked on: Topographische Karte, 1:25000, sheet Lyck (Ełk), 1937.

13 The inventory of the cemetery was carried out on 01.08.2016 


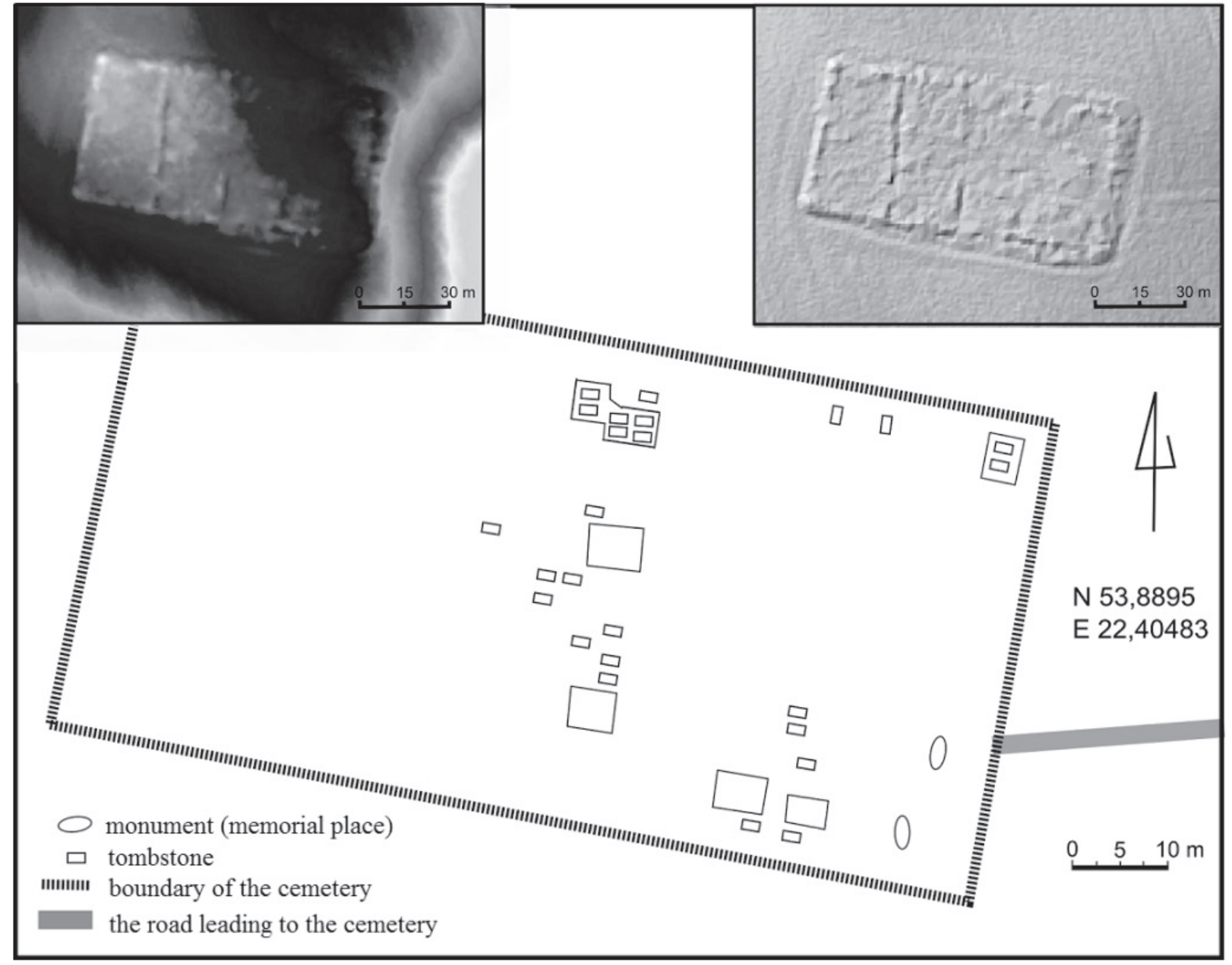

Fig. 7. Spatial development of the cemetery on the example of the site in Krokocie (Ełk County). Thumbnails (from left): hypsometric image with a dynamic color scale, LiDAR image

Source: Own study (LiDAR data from the ISOK project: www.geoportal.gov.pl [09/24/2016]).

I burials and the border line of the Evangelical cemetery. It turned out that part of the war cemetery with a monument crowning the central axis of the cemetery is located in the former religious necropolis. It was evidenced not only by the relics of the tombs of different origin (associated with the Protestant cemetery - probably from the 19th century) but also by the former border trench which is very difficult to see on the ground (Fig. 8).

On the above examples of the use of LiDAR system modules for prospecting the surface area of the cemetery, it can be concluded that the new research tools discussed here should be a constant element employed in studies of this type. It should be remembered, however, that the scanning visualizations available through the ISOK project, provided by Geoportal, have been developed based on the scanning accuracy of 4 points per $\mathrm{m}^{2}$. These data are not sufficient when trying to identify smaller surface objects (for instance, mounds whose relative heights sometimes do not exceed $0.5 \mathrm{~m}$, smaller ditches, relics of forest trails, or economic roads) showing slight hypsometric differences ${ }^{14}$. Unfortunately, certain inaccuracy in the land surface mapping results in limitations in the interpretation of the analyzed surface objects, and therefore, an integral part of the research should be, above all, terrain inspection allowing for verifying any doubts.

\section{Conclusion}

Many of the cemeteries which have been closed off for burial purposes, especially those managed by Jewish and Protestant communities until World War II, are now in poor condition. The Holocaust and population resettlement resulted in the lack of

14 The issue of problems with the accuracy of laser scanning measurements is raised by C. Sobczak (2015, pp. 43-44, 52-54). Based on his own research, he gives tips worth considering when planning airborne measurements and tips on the subsequent processing and interpretation of received images. 

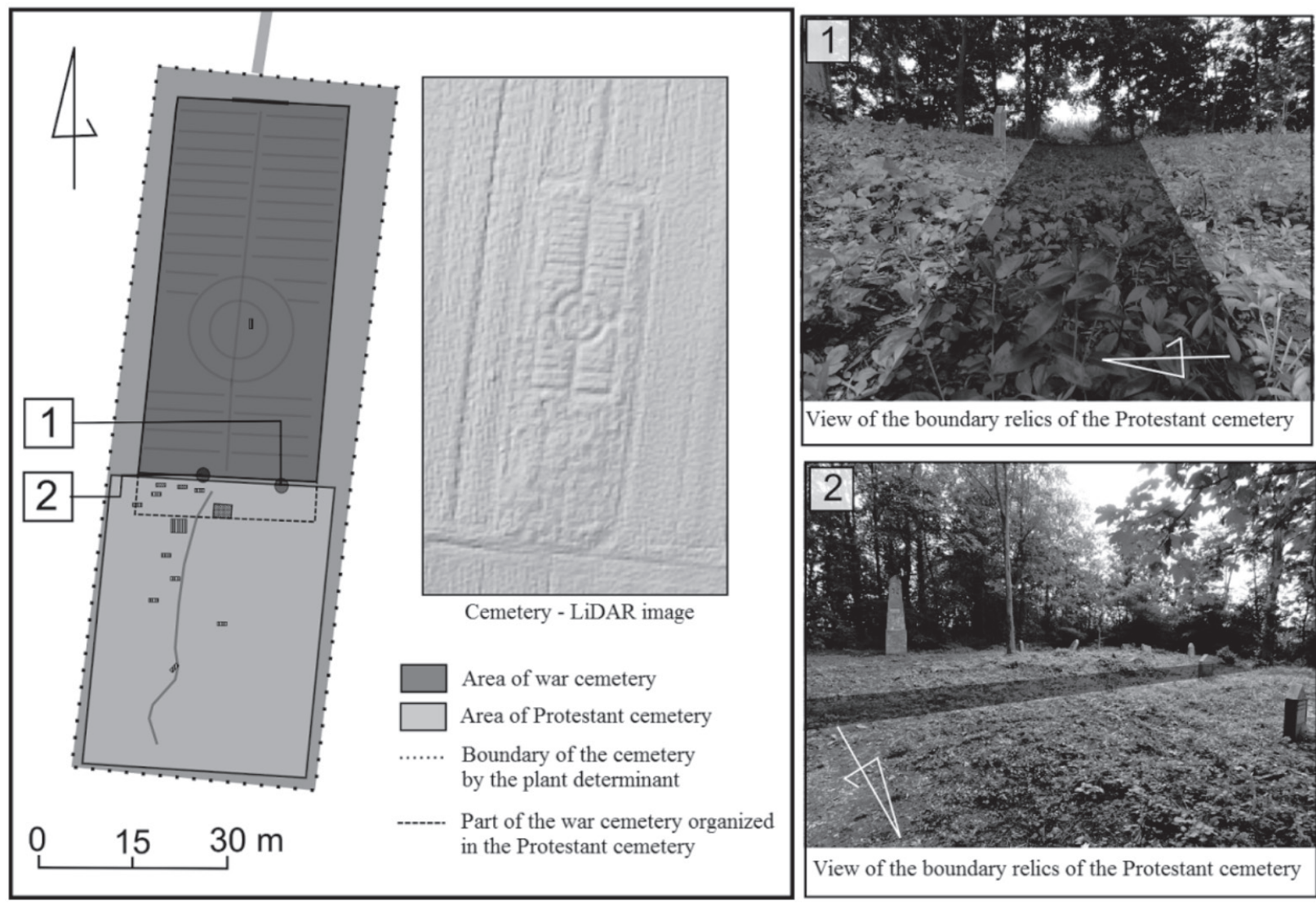

Fig. 8. Changes in the boundaries of burial space on the example of the cemetery in Bechcice (Pabianice County, Łódź Voivodeship)

Source: Own study (LiDAR image from the ISOK project: www.geoportal.gov.pl [24/09/2016]).

community which had had a direct relationship with the given sites. They are dependent upon the mercy of people who, in varying degrees, are sensitized to the need of saving the cultural heritage of the lands on which they live. Additionally, cemeteries are areas easily subject to modifications, where even the smallest human intervention can change the spatial context and scientific interpretation of the objects, for instance, as a result of cleaning up the land (by cutting once purposely placed plantings). Therefore, there is a need to develop non-invasive methods of studying burial sites, owing to which information can be obtained, among others, about the structure of the original cemetery, especially in areas difficult to access. A useful, and above all, effective tool in obtaining this type of information is LiDAR, which has been justified by the examples presented in the article. The results of research on the cemeteries conducted by the author would certainly be much poorer if had not been for the processed data from laser scanning. It would be impossible to outline many plans of the objects, without which the analysis of the cemetery is very difficult and does not bring results ${ }^{15}$.

15 No possibility of comparison of objects, among others, in
Part of the article on the Catholic cemetery in Lelów constitutes a scientific work funded under the programme of the Ministry of Science and Higher Education entitled "National Programme for the Development of Humanities" in the years 2014-2019.

\section{References}

Duma P., 2010, Grób alienata: pochówki dzieci nieochrzczonych, samobójców i skazańców w późnym średniowieczu i dobie wczesnonowożytnej, Wydawnictwo Avalon, Kraków.

Franczak P., Jucha W., 2015, Porównanie przydatności danych z kartowania terenowego i interpolacji modelu terenu wygenerowanego $z$ danych LiDAR do rozpoznania infrastruktury obronnej z II wojny światowej w Paśmie Jałowieckim, Prace Studenckiego Koła Naukowego Geografów Uniwersytetu Pedagogicznego w Krakowie, 4, 36-48.

http://www.geoportal.gov.pl/dane/numeryczne-modele-wysokosciowe [25/09/2016].

http://www.lidar-uk.com/usage-of-lidar/ [24/09/2016].

http://www.sztetl.org.pl/pl/article/janow/5,historia/ [25/05/2016].

terms of the location of tombstones in relation to the cemetery boundary. 
Komorowski W., 2011, Ulica, plac i cmentarz w publicznej przestrzeni miasta na przykładzie Krakowa staropolskiego, [in:] K. Wachowski (ed.), Ulica, plac i cmentarz w publicznej przestrzeni średniowiecznego i wczesnonowożytnego miasta Europy Środkowej, Uniwersytet Wrocławski, Instytut Archeologii, Wrocław, 31-41.

Lepionka H., 2014, Możliwości wykorzystania serwisów internetowych Google Earth oraz Geoportal w badaniach nad przeszłością na przykładzie dolnego odcinka doliny Supraśl, [in:] M. Zalewski, M. Zemło (eds.), Małe miasta. Perspektywa archeologiczna, Wydawnictwo KUL, Lublin-Supraśl, 251-264.

Majewska A., 2016, Żydowskie dziedzictwo religijne w przestrzeni województwa ślaskiego, typescript of the master's thesis defended at the University of Łódź.

Mszyca W., /no data/, Karta inwentaryzacyjna cmentarza żydowskiego w Żarkach, typescript.

Sobczak C., 2015, Lotnicze skanowanie laserowe wybranych obszarów Suwalszczyzny i jego weryfikacja terenowa, [in:] S. Wadyl, M. Karczewski, M. Hoffmann (eds.), Materiaty do archeologii Warmii i Mazur. T.1., Wydawnictwo UW, Warszawa-Białystok, 39-57.

Topographische Karte (Meßtischblätter) 1:25000 Lyck, 1937, Königliche Preussische Landesaufnahme; Reichsamt für Landesaufnahme, Berlin.

Wałdoch F., 2014, Spojrzenie na okolice Jeziora Charzykowskiego przez pryzmat lotniczego skanowania laserowego (LiDAR), Zeszyty Chojnickie, 30, 151-157.

www.geoportal.gov.pl [26.09.2016]. 